\title{
DEN STATSLIGE \\ ARBEJDSMARKEDSPOLITIK I KRISEN
}

\section{Bo Elling Nielsen}

Den følgende artikel kan læses i forlængelse af den analyse af den statslige arbejdsmarkedspolitik i perioden 1956 - 74, som jeg har fors $\emptyset \mathrm{gt}$ mig med i bogen Stat og arbejdsmarked.* Det væsentlige i det følgende vil være at afdække hvilke ændrede krav som krisegennemslaget har medført overfor en statslig arbejdskraftregulering, herunder reguleringen af selve arbejdskraftens pris. Problemet bliver altså, indenfor det her afgrænsede analysefelt, at undersøge hvilke indholdsmæssige ændringer krisen gennemtvinger overfor de statslige funktioner til varetagelse af kapitalforholdets reproduktion, og dermed hvordan disse indvirker på arbejderklassens reproduktionsbetingelser.

* Bo Elling Nielsen: STAT OG ARBEJDSMARKED. En analyse af den statslige arbejdsmarkedspolitik i Danmark 1950-1974. Kurasje 1977.

Ligesom denne bog er den følgende fremstilling på flere punkter mangelfuld og præsenteres ikke som nogen egentlig analyse, men snarere som en fremstilling af den faktisk førte statslige arbejdsmarkedspolitik siden krisens gennemslag i 1974. Den er således ikke baseret på en empirisk analyse, totalkapitalistisk og branchemæssigt, af kapitalens akkumulationsproces i krisen og dermed ej heller af kampbetingelserne og de faktisk førte kampe, som har fundet sted under det hidtidige kriseforløb, og som har været afgørende for den statslige politiks udformning og gennemsættelsesmuligheder. Artiklen er skrevet i januar 1978. 
I Stat og arbejdsmarked har jeg fors $\varnothing \mathrm{gt}$ at fremstille, hvorledes den stigende grad af overakkumulation indenfor den samfundsmæssigt anlagte totalkapital i begyndelsen af 1970erne leder til en modsætning mellem enkeltkapitalernes reproduktions- og akkumulationsform og sikringen af selve grundlaget herfor, nemlig arbejderklassens reproduktion som arbejdskraft. Denne modsætning fremkommer ved, at enkeltkapitalerne under det stigende tryk på profitraten nødvendigvis må reagere gennem en i stigende grad intensiv udnyttelse af arbejdskraften. Men dette er blot ensbetydende med, at de eksisterende problemer med arbejdskraftens reproduktion (nedslidning, udstødning, invalidering, m.m.) forstærkes således, at grundlaget for en kapitalreproduktion på længere sigt undergraves.

Denne udvikling fører til formuleringen af det, jeg har kaldt en omstillingsstrategi for totalarbejdsstyrken og som, kort fortalt, sigter på den for kapitalreproduktionen optimale fordeling af den samlede nationale arbejdskraft efter dennes funktionsmæssige ydeevne (jvf. Stat og arbejdsmarked s. 84-99). Jeg har desuden i bogen antydet hvorledes staten på dette punkt støder på dens institutionelle grænser, idet realiseringen af en sådan strategi vil kræve indgreb mod såvel selve salget som mod den kapitalistiske anvendelse af arbejdskraften, og dette vil være i fundamental modstrid med statens mere almene funktioner til sikring af privatejendommen og individernes dispositionsret over denne. ${ }^{1}$

\section{II.}

\section{Krisen og arbejderklassens reproduktion - reservearmeen}

Krisens endelige gennemslag i efteråret 1974 ændrer totalt denne problematik, hvad angår dens krav til statsapparatet overfor kapital- og arbejdskraftreproduktionen.

1. Dette må i det mindste siges at være gældende for såkaldte demokratiske (parlamentariske) statsformer indenfor den kapitalistiske produktionsmåde. Min tese er, at den nævnte strategi kun vil være mulig at realisere under fascistiske statsformer eller under en autoritær statskapitalisme. 
I krisen, som skyldes overakkumulation af samfundsmæssig totalkapital i forhold til den samfundsmæssigt producerede profitmasse, afsvækkes totalkapitalens akkumulation i forhold til dens hidtidige niveau. Det samfundsmæssige reproduktionsproblem bliver derfor, at genetablere betingelserne for en udvidet totalkapitalistisk akkumulation gennem en forøgelse af den samfundsmæssigt producerede profitmasse (som vil være ensbetydende med en forhøjelse af den samfundsmæssige udbytningsgrad). Den fundamentale proces, der skal sikre denne udvidelse af profitproduktionen, er krisen selv ved, at dens rensende virkning gennemsættes således, at de mindst profitable kapitaler destrueres og de $\emptyset$ vrige kapitaler forøger deres profitabilitet.

Krisen betyder at arbejdskraft overflødigg øres (frisættes) gennem den skærpede konkurrencekamps destruktion af kapitaler og ved de tilbageblevne kapitalers bestræbelser på at $\emptyset$ ge deres profitabilitet. Dette kan ske gennem forskellige former for $\emptyset$ konomisering med den konstante eller med den variable kapital. ${ }^{2}$ Særligt $\varnothing$ konomisering med den variable kapitaldel fører til en intensivering af arbejdet og en reduktion i antallet af beskæftigede arbejdere.

Den i krisen frisatte arbejdskraft udgør samtidigt en del af grundlaget for, at kapitalerne kan følge de nævnte kriseløsningsstrategier, idet den stigende arbejdsløshed fører til øget konkurrence mellem sælgere af arbejdskraft.

Den industrielle reservearme, som udvikles i krisen, vil derfor både være bestemt af kapitalakkumulationens hidtidige forløb inden krisen og af de kriseløsningsstrategier, som kapitalerne gennemsætter (har mulighed for at gennemsætte) i krisen. Dette er derfor også ensbetydende med, at selve reservearmeens sammensætning kan ændres efterhånden som krisen uddybes og dens renselsesprocesser forløber.

Den reservearmé, som etableres i efteråret 1974 og i løbet af året 1975, består af især 4 specifikke grupper:

I: Aldre nedslidte arbejdere, som ofte er frisat i krisens begyndelsesfaser, jvf. tabel 2. ${ }^{2}$

2. Disse $\varnothing$ konomiseringsbestræbelser kan tage form af 1) forkortelse af produktionstiden (formindskelse af $\mathrm{k}$ og v) gennem teknologisk udvikling, 2) forøgelse af arbejdsproduktiviteten (forøgelse af $\mathrm{m}$ og ofte formindskelse af v) gennem intensivering af arbejdet, ændring i lønsystemer, organisationsformer, mv, 3) forlængelse af arbejdsdagen (forøgelse af $\mathrm{m}$ og ofte af v) 4) sænkning af arbejdslønnen (forøgelse af m) 5) økonomisk anvendelse af den konstante kapital gennem stordrift (centraliseringer) og 6) en økonomisering med det arbejde, der bidrager til at producere den konstante kapital gennem udvikling af den samfundsmæssige arbejdsdeling, anvendelse af videnskab og teknologi, mv. (denne sidste mulighed ligger kun i begrænset omfang indenfor enkeltkapitalernes handlingsmuligheder). Eksemplerne her er taget fra Tyge 
II: Unge, som ofte går lige fra grundskolen eller fra en læreplads ud i arbejdsløshed, jvf. tabel 2. ${ }^{2 \mathrm{a}}$

III: Ufaglarte arbejdere (specialarbejdere) som har vanskeligt ved at omstille sig til nye arbejdsprocesser, jvf. tabel 3, herunder:

IV: Kvinder, jvf. tabel 2, 3 og 4.

Jeg skal meget kort yderligere begrunde det udviklingsforløb, som fører til en sammensætning af den industrielle reservearmé med netop disse 4 hovedgrupper.

\section{Ad I. AEldre nedslidte arbejdere}

Da intensiveringen af arbejdsprocessen fortsætter med forøget styrke i krisen, fremtvunget dels af renselseskrisens nødvendighed og dels af arbejderklassens manglende mulighed for at udøve modstand, sker der en forøget nedslidning af arbejdskræfter med endelig udstødning fra produktionsprocessen til følge, da disse, når det især drejer sig om ældre arbejdskræfter, har endnu vanskeligere ved at opfylde kapitalens krav om hurtighed, udholdenhed, o.s.v. Men denne udstødning »skjules« nu i massearbejdsløsheden specielt i form af langtidsarbejdsløshed.

Hvor denne udstødning før krisen tendentielt betød problemer for den totalkapitalistiske reproduktion, dels fordi den betød en yderligere reduktion af arbejdsstyrken og dels fordi den betød et fradrag i den nationale akkumulationsfond gennem en stigning i de offentlige budgetter, kan den nu, direkte modsat, have en, i forhold til kapitalreproduktionen, progressiv effekt hovedsageligt fordi, den giver plads til yngre arbejdskræfter, der ellers ville gå arbejdsledige, og som er mere produktive og omstillelige end de ældre og nedslidte arbejdere.

\section{Ad II. Unge arbejdere}

Ungdomsarbejdsløsheden skyldes hovedsageligt, at for de enkelte kapitaler er de yngre erhvervs-optranede arbejdskræfter, som frisættes ved krak og indskrænkninger i andre virksomheder, de mest produktive.

Kjær: Nogle eksempler på enkeltkapitalistiske kriseløsningsstrategier. I Økonomi og teknologi i perioden 1960-75. TEK-SAM RUC 1977.

2a Den reelle arbejdsløshed for ældre og unge er betydeligt større end det fremgår af tabel 2. Den del af de ældre som tvinges til at forlade arbejdsmarkedet indgår jo ikke i statistikken. For de unge gælder det, at et meget stort antal ledige unge ikke er registreret på AF-kontorerne, særligt unge under 18 år. Det samlede antal arbejdsløse unge vurderes officielt til at ligge på omkring 70.000 i jan. 1978. Se Nyt fra Danmarks Statistik nr. 25 7. feb. 1978. 
Sålænge disse findes på markedet, er det derfor især dem som opsuges ved øget efterspørgsel og udskiftninger i den beskæftigede del af arbejdsstyrken. Derfor har unge, som kommer lige fra grundskolen eller grunduddannelsen, som ofte er adskilt fra den egentlige produktionsproces, svært ved at opnå beskæftigelse, hvis ikke de kan anvendes som ekstrem billig arbejdskraft:

- de er enten ikke specifikt erhvervsuddannede, eller

- de er ikke erhvervsoptrænede eller erfarne og

- de er oftest ikke disciplinerede til produktionsprocessen.

Der kan i denne henseende peges på de stigende vanskeligheder for EFG-elever med at opnå praktikpladser, mens der er et stigende antal tilbud om at gennemgå den traditionelle mesterlære (jvf. det følgende under pkt. IV. 3.).

Umiddelbart medfører dette ikke noget problem hvad angår den beskæftigede arbejdsstyrkes produktivitet, men på længere sigt kan en udvikling, som betyder, at størsteparten af en årrækkes unge arbejdskræfter ikke integreres i den beskæftigede del af arbejdsstyrken (dvs. ikke reproduceres som arbejdskraft), være ensbetydende med, at arbejdsstyrken $i k k e$ reproceres $\mathrm{i}$ en for kapitalreproduktionen tilstrækkelig produktiv form. ${ }^{3}$

\section{Ad III. Ufaglarte (specialarbejdere)}

At en forholdsvis stor andel af reservearmeen består af ufaglærte skyldes, at disse, på grund af deres manglende eller specielle uddannelse, ofte har vanskeligt ved at omstille sig til nye arbejdsfunktioner, hvis de tvinges ud af deres hidtidige beskæftigelse og, at disse arbejdere oftest er beskæftiget i de arbejdsintensive delprocesser indenfor de enkelte brancher. Det vil netop være indenfor disse arbejdsintensive processer, der vil kunne frisættes

3. Her må det også fremhæves, at den høje ungdomsarbejdsløshed ikke blot skyldes, at de unge kræver oplæring inden de er tilstrækkeligt produktive for kapitalen, som det bl. a. er nævnt i det foregående. Jvf. netop de mange lærlinge som på forhånd er fyrede, når deres læretid udløber. Disse er jo netop erhvervsoptrænede, men da nyoptaget på de fleste virksomheder er meget begrænset i forhold til afgangen, vil ansættelse af nyudlærte svende ofte skulle ske på bekostning af allerede ansatte svende. Heri ligger reelt en interessemodsætning (dvs. splittelsesgrundlag) mellem lærlinge og svende. Dette kan bl. a. være grundlaget for splittelsen mellem lærlingenes landsorganisation LLO og LO, som er blevet stadig uddybet i krisen. I løbet af 1977 har dette ført til at LO fratog LLO $\varnothing$ konomisk støtte og en række store forbund udmeldte kollektivt deres lærlinge af LLO, og oprettede nye lærlingeorganisationer, der reelt kontrolleres af fagforbundene og LO. 
arbejdskræfter ved en forøget intensivering af arbejdet, da der oftest ikke sker nogen tilsvarende udvidelse af produktionsanlægget i krisen.

Men de ikke-faglærtes særligt høje arbejdsløshed skyldes ikke alene, at det specielt er deres arbejdsområder der rammes i krisen, men også at de faglærtes omstillelighed m.v. gør det muligt for dem at gøre indhug på de ikke-faglærtes arbejdsområder. Dette vil derfor ofte føre til modsætninger mellem disse to grupper omkring imødegåelse af kapitalernes kriseløsningsstrategier.

\section{Ad IV. Kvinder}

At kvindearbejdsløsheden indenfor alle brancher er højere end mændenes, skyldes i hovedsagen, at kvinderne især er beskæftiget indenfor de arbejdsintensive delprocesser i industrien. ${ }^{4}$ De er derfor tilsvarende de ikke-faglærte mænd, som er beskæftiget i disse processer, udsat for en større arbejdsløshedsrisiko. Men kvindearbejdsløshedsprocenten bliver højere end mændenes, fordi der før krisen var en relativ større andel af kvinderne, der udførte sådant arbejde, end det var tilfældet blandt mændene. ${ }^{5}$

4. Der er for visse brancher ikke blot tale om at der i de arbejdsintensive delprocesser særligt beskæftiges kvinder, men at langt den overvejende del af det samlede antal beskæftigede er kvinder. Det er bl. a. tilfældet for textil-, fodtøj- og beklædningsbrancherne.

5. Dette må ses som den væsentligste baggrund for den relativt større kvindearbejdsløshed, men heri ligger selvfølgelig ikke nogen forklaring på denne. Hertil fordres en analyse af kvindernes arbejdsmæssige placering, specielt indenfor industrien, deres betydning som arbejdskraftreserve, som billig arbejdskraft, i relation til familien og familiearbejdet, osv., kort sagt en analyse af hvorfor kvinderne specielt er beskæftiget indenfor de pågældende arbejdsprocesser, i efterkrigstiden frem til krisen i 1970erne og hvilken ændring, denne har betydet for disse forhold. Forlaget Modtryk's udgivelsesserie Kvindearbejde og kvindekamp, indeholder en del af denne analyse. Se Brita Foged: Kvindearbejde 1950-71. Margit Christensen, m. fl.: Kvinder i elektronikindustrien. Ruth Emerik og Birte Siim: Kvinders arbejds- og levevilkår. Anette Borchorst, m. fl.: Hvor gik kvinderne hende da de gik ud? I efterskriftet til Brita Foged, nævner Randi Markussen og Birte Siim følgende forhold som værende af afgørende betydning for kvindernes svagere stilling på arbejdsmarkedet, som specielt kommer til udtryk i krisen: »a) en løsere tilknytning (til arbejdsmarkedet) f.ex. pga. deltidsarbejde eller fravær fra produktionen gennem længere tid, b) dårligere kvalifikationer, der gør det lettere at bortrationalisere kvinderne under en krise, c) dobbeltarbejdet giver også en løsere tilknytning og en mere udsat position, d) kvinderne er ofte placerede i konjunktur-, og (struktur), følsomme brancher og sektorer, og e) endelig er de dårligere organiserede og har færre kamptraditioner.« (s. 133). 
Disse fire grupper er de mest karakteristiske for, hvad Marx kalder, den relative overbefolknings akutte fremtrædelse under krisen (Kapitalen 1. bog 4 s. 902). I det følgende (pkt. IV) skal jeg beskæftige mig med, hvorledes denne specifikke sammensætning af den industrielle reservearmé på den ene side fremtvinger bestemte indgreb overfor arbejdskraftreproduktionen, og hvorledes de statslige indgreb overfor arbejdskraftreproduktionen på den anden side indvirker på reservearmeens sammensætning og funktion.

Her kan vi i første omgang konstatere, at den samlede industrielle reservearmé, er et udtryk for, at krisen betyder reproduktionsvanskeligheder for arbejderklassen som helhed, herunder særligt vanskeligheder med dens (arbejderklassens) reproduktion som arbejdskraft i og med spaltningen i beskæftigede og arbejdsløse. Men denne manglende reproduktion udgør ikke, som det tendentielt var tilfældet under reproduktionsbetingelserne før krisens gennemslag, nogen skranke for totalkapitalens reproduktions- og akkumulationsproces; den er tværtimod et resultat af, at skranken for kapitalreproduktionen ligger i kapitalen selv, som relativ overakkumulation og manglende profitabilitet.

Krisen ophæver således den skranke for kapitalens akkumulation, som arbejderklassens reproduktions- og cirkulationsproces fremtræder som før krisen $^{6}$, først og fremmest ved at manglen på arbejdskraft, herunder mangel på tilstrækkelig produktiv arbejdskraft, ikke længere gør sig gældende og ved, at arbejderklassens muligheder for at udøve modstand mod enkeltkapitalernes intensivering af arbejdet undermineres af reservearmeens eksistens og truslen om arbejdsløshed. Den statslige politik, som sigter på at ophæve en sådan skranke, er dermed også overflødiggjort.

6. For at undgå mistorståelser: Der er naturligvis ikke tale om, at det er arbejderklassens cirkulations- og reproduktionsproces der er det egentlige grundlag for de stigende vanskeligheder for kapitalreproduktionen i begyndelsen af 1970erne, men omvendt, som nævnt i det foregående, er det den faldende profitrate siden midten af 1960erne, som tvinger enkeltkapitalerne til en mere intensiv udnyttelse af arbejdskraften, og som bevirker de stigende vanskeligheder for arbejderklassens reproduktion som arbejdskraft. Dette forstærker ganske vist kapitalens reproduktionsvanskeligheder, da arbejderklassen svarer igen ved at udøve modstand mod kapitalens intensiveringsbestræbelser, bl.a. ved at tilkæmpe sig lønkompensationer, og ved at mangelen på arbejdskraft bliver forstærket af udstødningen.

Krisens ophavelse af denne skranke sker altså ved, at de egentlige kriseårsager nu fremtrader i deres »sande skikkelse" som overakkumulation af samfundsmaessig totalkapital. Dette er selvfølgeligt ikke ensbetydende med, at de egentlige kriseårsager erkendes, f.eks. af de borgerlige $\emptyset$ konomer, men krisens »sande « konsekvenser i form af krak, braklægning af kapital og massearbejdsløshed, kan de jo ikke løbe fra. 
Jeg skal i det følgende forsøge at vise, hvorledes dette da også fører til en fundamental ændring af de statslige interventioner og disses former overfor arbejdsmarkedet og arbejdskraftreproduktionen, og fors $\emptyset$ ge yderligere at begrunde, hvad der betinger disse ændringer. Forinden skal jeg ganske kortfattet omtale den statslige krisepolitik generelt, og særligt dennes finansielle former.

\section{Krise og stat}

En statsmagt som i en krise vil påvirke kapitalens renselsesproces, med henblik på at genetablere profitproduktionens betingelser, har, ifølge den borgerlige nationaløkonomi, meget groft set to alternativer: - Det ene, som foreskrevet af den neoklassiske фkonomiske teori, er i hovedsagen at lade kapitalens renselsesproces forløbe frit, dvs. uden statslig intervention i markedskræfternes frie spil og samtidig nedskære de offentlige uproduktive udgifter (eksempelvis udgifterne til socialforsorg og uddannelsesforanstaltninger), da disse medvirker til at skabe et »unaturligt« højt prisniveau. Bag denne opfattelse hos neoklassikerne ligger antagelsen om, at der i det $\varnothing$ konomiske system eksisterer en naturlig tendens til opretholdelse af ligevægt: på varemarkedet således, at udbuddet svarer til efterspørgslen og på arbejdsmarkedet således, at enhver har beskæftigelse. ${ }^{7}$

Men denne ligevægtstilstand forudsætter fuldstændig fri konkurrence og fuldt bevægelige arbejdskræfter, og det er derfor, ifølge neoklassikerne, den lønpolitik som staten og fagforeningerne fører, som er årsagen til en tilstand, hvor der eksisterer arbejdsløshed. For statens vedkommende gennem at den sikrer mindste-lønninger eller, at den bidrager til arbejdsløshedsunderstøttelsen - fagforeningerne ved, at de udnytter en gunstig beskæftigelsessituation til at presse lønningerne unaturligt $\mathrm{i}$ vejret, eller, at de gennem en monopolistisk politik ved salget af arbejdskraften hindrer dens frie bevægelighed.

7. En af neoklassikerne, Pigou, formulerer det således: »Ved fuldstændig fri konkurrence mellem arbejderne og ved fuldt bevægelige arbejdskræfter ..., vil der til stadighed virke en stærk tendens mod at tilpasse lønsatserne til efterspørgslen således, at enhver har beskæftigelse.« (Citeret fra W. Hofmann: Sozialökonomische Studientexte. Band 2. Berlin 1963 s. 251). 
- Det andet alternativ er, som foreskrevet i den keynesianske фkonomiske teori, at tilskynde til nyinvesteringer ved at stimulere efterspørgslen gennem statslig udpumpning af købekraft ved deficitfinansiering. Ifølge Keynes er det nemlig en aftagende forbrugstilbøjelighed, ved stigende indkomst, der medfører en aftagende investeringstilbøjelighed hos fabrikanten (kapitalisten), som er årsagen til den tilstand, hvor der hersker høj arbejdsløshed. Derfor må efterspørgslen stimuleres. Ved den statsligt finansierede efterspørgsel skabes der, via den såkaldte multiplikatoreffekt ${ }^{8}$, yderligere efterspørgsel, investering, indkomst, forbrug, osv. i en vis aftagende afsmitningsgrad afhængig af forbrugskvoten. I modsætning til neoklassikerne, der udelukkende betragter lønnen som en omkostningsstørrelse for virksomhederne, fokuserer keynesianerne på lønnens efterspørgselsmæssige virkninger for den samlede $\varnothing$ konomi. ${ }^{9}$ Hvor neoklassikerne anser en reduktion af den samlede lønsum som en direkte nødvendighed i krisen, vil keynesianerne anse dette for at have en direkte skadelig virkning på investeringer og beskæftigelse, da det jo blot vil betyde en reduktion af den samlede nationale efterspørgsel. ${ }^{10}$ Historisk satte 30'ernes krise et alvorligt spørgsmålstegn ved den neoklassiske teori om ligevægt på arbejdsmarkedet. Selv i lande hvor staten traditionelt ikke havde interveneret $\mathrm{i}$ arbejdsmarkedet og hvor fagforeningerne stod svagt, var arbejdsløsheden uhyggelig høj (f.eks. USA og Frankrig).

Keynes formulerede sin teori i 1936 bl. a. på baggrund af erfaringerne fra de kapitalistiske krigsøkonomier under 1. verdenskrig og fra fascismen i Italien og Tyskland i 1920erne og 30erne samtidig med, at statsmagten i forskellige kapitalistiske lande forsøgte en politik med en statslig stimulering af efterspørgslen (herhjemme ved statslige beskæftigelsesarbejder og statsligt forbrug koblet sammen med en statslig lønbegrænsningspolitik). ${ }^{11}$ Men den egentlige betydning for den statslige

8. En kritik af Keynes findes hos Paul Mattick: Marx og Keynes. Kbh. 1973. En kritik af multiplikatorteorien, specielt s. 140-144.

9. Dette er selvfølgelig ikke Keynes' opfindelse. Foruden Marx, betonede R. Hilferding særligt dette, se Das Finanzkapital. EVA Frankfurt a M Band II s. 499.

10. Men Keynes afholdt sig ikke fra at anvise hvorledes lønsumsreduktioner bedst opnås. Hvis lønsumsreduktioner opnås gennem en sænkning af nominallønningerne (altså lønstørrelsen i f.eks. kr. og ører) skaber det, i følge Keynes, for meget modstand fra arbejderklassen og tab som følge af strejker mv. Derfor anbefaler Keynes, at reduktionen sker ved at lønningerne stiger mindre end priserne. Herved opnås en reallønsænkning samtidig med at nominallønninger godt kan stige.

11. Keynes videreudviklede en række samtidige $\varnothing$ konomers arbejder. Bl. a. Gunnar Myrdal, hvis anbefaling af en ekspansiv finanspolitik som et led i en konjunkturstimulering under krisen, blev 
Herhjemme var den keynesianske $\varnothing$ konomiske politik i denne periode et vigtigt led i den statslige konjunkturreguleringspolitik, herunder i 60erne en inflationspolitik, samtidigt med, at visse af neoklassikernes forskrifter blev anvendt; først og fremmest blev det gennem en bevægelsesfremmende politik overfor arbejdskraftcirkulationen fors $\emptyset \mathrm{gt}$ at skabe de markedsmæssige forudsætninger for, at prisen på varen arbejdskraft kunne tilpasses de akkumulationsmæssige imperativer. ${ }^{12}$

Keynes og hans efterfølgere beskæftigede sig ikke med den keynesianske finanspolitiks begrænsninger. ${ }^{13}$ Historisk fremtrådte disse begrænsninger i slutningen af 1960erne og begyndelsen af 70erne i form af den statsligt initierede akkumulations stagnation sammen med en galoperende inflation. Yderligere fors $\emptyset \mathrm{g}$ på en statslig stimulering af akkumulationen gennem en udvidelse af efterspørgslen, fører, sammen med det stigende statslige forbrug i $\varnothing v$ vigt, blot til et fald i den akkumulerbare profitmasse og til yderligere inflationsprocesser, der også virker hæmmende på akkumulationen. Krisegennemslaget var i sig selv det klareste udtryk for disse grænser, da det jo ikke var lykkedes at forhindre det med de keynesianske reguleringsmekanismer, selv om det $\mathrm{i}$ årevis var blevet udbasuneret som mulighed.

De finansielle kriseindgreb har da også med al ønskelig tydelighed vist deres ofte modsætningsfyldte virkemåde og magtesløshed overfor krisens tvangsmekanismer. I denne situation har den såkaldte $\varnothing$ konomiske sagkundskab, som ellers siden krigen herhjemme har været stærkt domineret af forskellige varianter og videreudviklinger af Keynes ${ }^{14}$, atter vendt sig mod varianter af neoklassisk teori, specielt den såkaldte monetarisme. ${ }^{15}$ Jeg skal ikke behandle denne her, ej heller analysere dette skifts eventuelle betydning for den førte $\varnothing$ konomiske politik, men henvise til publikationen fra Det $\varnothing$ konomiske Råd.

introduceret herhjemme i 1934 af Jørgen S. Dich i artiklen: Offentlige arbejder som middel mod arbejdsløsheden, i Særtryk af Nationaløkonomisk Tidsskrift, 1934 s. 149-170. økonomiske politik fik Keynes' teori ikke primært under krisen, men i 1950ernes og 60ernes højkonjunktur.

12. Se Stat og arbejdsmarked s. 69-84.

13. Jeg skal ikke her give en fremstilling af disse, men henvise til Mattick, op. cit., hvor de først og fremmest er blevet formuleret.

14. En grundig teorihistorisk analyse af neoklassisk teori samt Keynes, og teoretiske videreudviklinger heraf i 1950erne og 60erne, specielt hvad angår disses lønteoretiske ansatser, findes hos Erling Havn: Om fagforeninger og lønpolitik. Kbh. 1977.

15. Se Det $\varnothing$ konomiske Råd: Dansk Økonomi. April 1976. s. 13-31. 
I takt med krisens gennemslag og uddybelse har krisepolitikken fulgt et mønster, der groft kan sammenfattes i to faser:

En første fase (ca. 1974-75) hvor den har forsøgt at hindre krisetilbageslaget, m.h.p. en forventet ny højkonjunktur, dvs. forhindre udrensning af kapitaler (nedlæggelse af kapacitet) ved, at give finansielle tilskud til kapitaleme (de såkaldte omkostningsdæmpende ydelser) og ved, modsvarende hertil, at forøge den samlede efterspørgsel (skattelettelser, besparelser på de statslige budgetter, midlertidig sænkning af momsen). Men denne politik kunne ikke forhindre en voldsom stigning i massearbejdsløsheden, besparelserne bidrog direkte til dens udvidelse, og betød samtidig 1) at de inflationære tendenser forstærkedes, 2) at krisens renselsesprocesser (udrensning af de mindst profitable kapitaler, løntryk, m.m.) blev udskudt eller hæmmet, hvad der i første omgang også var meningen, men som betyder forøgede vanskeligheder, når krisen forstærkes og dens renselsesprocesser ikke har fået lov at virke fuldt ud, og 3) forøget statsgælden og dermed forфget det fremtidige fradrag i akkumulationsfonden, der må gå til renter og afdrag på gælden, og derigennem bidraget til en udtømning af krisepolitikkens finansieringsmuligheder.

I anden fase (fra ca. 1976), da det uomtvisteligt er en $\varnothing$ konomisk krise af længerevarende karakter man står overfor, sker der da også en drastisk omlægning af politikken, og den mangeårige snak om indkomstpolitik bliver til virkelighed i form af en statslig lønbegrænsningspolitik. Hovedsigtet i krisepolitikken bliver nu at forøge den såkaldte investeringstilbøjelighed gennem en forhøjelse af kapitalernes profitrater og en nedbringelse af betalingsbalanceunderskuddet. Dette forsøges opnået gennem en reduktion i kapitalernes kostpriser, specielt den variable kapitaldel (lønbegrænsningspolitikken) og ved en opsugning af købekraft gennem skatte- og afgiftsforhøjelser. Begge former for indgreb medvirker desuden til en udrensning af de mindst profitable kapitaler, da de medfører en kraftig reduktion i efterspørgslen. Samtidig medfører indgrebene en stærk forøgelse af arbejdsløsheden, som det fors $\varnothing$ ges at råde lidt bod på gennem de såkaldte beskæftigelsesplaner, der består af forskellige former for tilskud til bestemte arbejders udførelse, herunder egentlige beskæftigelsesarbejder. ${ }^{16}$

16. En vurdering af augustforlig I og II (1976 og 1977) findes hos regeringens egne $\varnothing$ konomiske vismænd i beretningerne fra Det økonomiske Råd: Dansk økonomi. November 1976, s. 67 og Dansk økonomi. December 1977. s. 46. Her vurderes såvel de samlede virkninger af forligene m. h. t. beskæftigelse og betalingsbalance, som virkningerne af de enkelte dele, dvs. 
Anden fase af den statslige krisepolitik er således stærkt medvirkende til en udvidelse af massearbejdsløsheden. Dette sker gennem en omlægning af de finansielle indgreb til at virke i retning af en begrænsning af den samlede efterspørgsel samtidig med, at hovedvægten i den statslige krisepolitik forskydes fra de finanspolitiske virkemidler til bestræbelser på at opnå de tilsigtede virkninger gennem direkte indgreb i fastsættelsen af lønningerne. Herigennem foregriber og underst $\varnothing$ tter den statslige krisepolitik de renselsesprocesser, specielt reservearmeens tryk på lønningerne og udrensningen af de mindst profitable kapitaler, som den i den første fase var medvirkende til at hæmme eller udskyde.

Jeg skal ikke yderligere beskæftige mig med den statslige krisepolitik generelt. Formålet med det foregående har først og fremmest været at vise begrænsningerne i de finansielle kriseindgreb og deres ofte modsigelsesfyldte virkemåde, for derigennem at indplacere den følgende gennemgang af de statslige politikker, som retter sig direkte mod arbejdsmarkedet, herunder de omtalte lønindgreb, i den rette sammenhæng. Det skal således vises, hvorledes den retlige interventionsform tiltog i takt med vanskelighederne omkring de financielle indgreb.

\section{Stat og arbejdsmarked i krisen}

Som anført i det foregående kan der, som følge af krisens fundamentale omvæltning af forholdene på arbejdsmarkedet, konstateres et meget markant skift i de statslige politikker, som rettes direkte mod arbejdsmarkedet og desforuden en $\emptyset$ get vægt på disses retlige indgrebsformer. ${ }^{17}$

Hvor den indirekte lønregulering gennem arbejdsmarkedspolitikkens omstillingsforanstaltninger m.v. og inflationens virkninger var domine-

af lønindgrebet, afgiftsforhøjelseme og af de såkaldte beskæftigelsesplaner. Augustforlig I's beskæftigelsesmæssige virkninger har været stærkt diskuteret, jvf. det følgende. Virkningen af forligets beskæftigelsesfremmende foranstaltninger må siges at være stærkt begrænsede. Jvf. interview med Preben Wilhjelm i Politisk Revy nr. 315.

17. Om de statslige interventionsformer på arbejdsmarkedet, se Stat og arbejdsmarked, s. 56-60. 
rende i 1960erne og begyndelsen af 1970erne, fremtvinger krisen direkte statslige indgreb i lønfastsættelsen.

Hvor arbejdsmarkedspolitikken i 1960erne var rettet mod en omstrukturering af kvalifikationsstrukturen for den samlede arbejdsstyrke og i begyndelsen af 1970erne blev formuleret som en strategi for den samlede arbejdsstyrkes reproduktion som arbejdskraft (jvf. Stat og arbejdsmarked s. 84-100), medfører krisen, at den statslige arbejdsmarkedspolitik foruden de direkte lønindgreb - koncentreres om stærkt selektive indgreb overfor arbejdsstyrkens reproduktion som arbejdskraft.

\section{Statsindgreb overfor lønstørrelsen}

Jeg vil indledningsvis forsøge at skitsere baggrunden for at statsindgreb overfor lønstørrelsen bliver en central del af den statslige krisepolitik; herunder vil jeg omtale nogle forskellige virkninger af lønindgreb.

En statslig lønpolitik som sigter på at begranse lønudviklingen har til formål at hæve profitkvoten og dermed den akkumulerbare andel af den producerede merværdimasse. Herigennem håber man også på at opnå en forbedret konkurrenceevne overfor udlandet. At en sådan statslig lønpolitik overhovedet bliver en $\emptyset$ nskelig mulighed skyldes følgende forhold.

Det totale nationale værdiprodukt er alene afhængigt af antallet af produktive arbejdere og af den samfundsmæssige udbytningsgrad. En udvidelse af det samlede antal produktive arbejdere vil altså forøge det nationale værdiprodukt, men det vil ikke have nogen virkning m.h.t. det som er det egentlige problem i krisen, nemlig en forøgelse af kapitalens profitabilitet. Hertil må der ske en udvidelse af det nationale værdiprodukt gennem en højnelse af den samfundsmæssige udbytningsgrad. De enkelte kapitaler har imidlertid ikke nogen umiddelbar mulighed for at påvirke udbytningsgraden, da den er en samfundsmæssig bestemt størrelse. De enkelte kapitaler kan gennem forskellige former for omkostningsreduktioner, eksempelvis en mere intensiv udnyttelse af arbejdskraften, opnå en større andel af den totalt producerede profitmasse, men dennes størrelse (det vil sige hvad der samlet er til rådighed til fordeling mellem de enkelte brancher og imellem de enkelte kapitaler indenfor brancherne) påvirkes ikke umiddelbart af enkeltkapitalernes forskellige manipulationer, da den er samfundsmæssig bestemt gennem den samfundsmæssige udbytningsgrad. 
Det er dette forhold der bevirker, at et statsligt lønindgreb, som betyder en generel sænkning af lønningerne, er et effektivt middel til at sikre samtlige enkeltkapitaler en umiddelbar omkostningsreduktion, idet et indgreb betyder en omfordeling i forholdet mellem løn og profit, til profittens fordel. Altså kort sagt: en umiddelbar forøgelse af den samfundsmæssige udbytningsgrad.

Et lønindgreb forekommer derfor at være et effektivt og yderst oplagt middel i en statslig krisepolitik, når vi som udgangspunkt tager, at det som, kapitalistisk set, må ske i krisen, og det som i sidste instans skal ophæve den, er, at kapitalens samfundsmæssige profitabilitet forøges.

Virkningerne af lønindgreb er imidlertid (afhængigt af indgrebets konkrete udformning) forskellige og oftest modsigelsesfulde.

I det følgende vil jeg omtale virkningerne på 3 områder:

a. beskæftigelsesmæssige virkninger, d.v.s. på antallet af beskæftigede.

b. virkninger m.h.t. krisens renselsesprocesser.

c. virkninger m.h.t. den i produktionsprocesserne anvendte teknik.

\section{a. Beskaftigelsesmassige virkninger}

En reduktion af den samlede lønsum vil betyde en forøgelse af den samfundsmæssige udbytningsgrad, og dermed en omfordeling mellem løn og profit til profittens fordel. Ser vi på dette generelt, så håber man herigennem, at opnå en stigning i nyinvesteringerne da den akkumulerbare merværdi forøges og arbejdskraft bliver billigere. Samtidig håber man på en forbedring af konkurrenceevnen overfor udlandet, som også skulle forøge investeringer og beskæftigelse. Men den negative virkning er en reduktion af købekraften og dermed af efterspørgslen.

Da en reduktion af lønsummen specielt rammer de almindelige daglige forbrugsnødvendigheder og ikke luxusforbruget, vil dette fald i efterspørgslen specielt ramme konsummiddelsektoren, d.v.s. industrier med et stort arbejdskraftforbrug. Dette medfører altså på den anden side en for$\emptyset$ gelse af arbejdsløsheden, som så i øvrigt betyder en yderligere reduktion af købekraften og dermed yderligere arbejdsløshed. En del af denne effekt kompenseres til en vis grad af den købekraft, der opretholdes gennem den statsligt finansierede arbejdsløshedsunderstøttelse, men afgørende herfor er selvfølgelig om det statslige bidrag finansieres over skatterne eller ved låntagning i udlandet. Men totalt set må den arbejdsløshed som en reduk- 
tion af lønsummen skaber, modstilles den effekt som en sådan politik kan have i retning af at forøge beskæftigelsen. (Ang. nettovirkningerne mht. beskæftigelsen, se det følgende).

\section{b. Virkninger m.h.t. krisens renselsesprocesser}

I det følgende vil jeg specielt omtale hvorledes reduktion af forventede lфnstigninger kan foregå, d.v.s. hvorledes man kan fastsætte et maximum for lønsummen. Der er i princippet 2 måder at gøre dette på:

1. gennem en fastfrysning af de eksisterende uligheder i lønningerne (lønstrukturen) ved at give éns \%-tillæg, eller det samme (i kroner og ører) til alle arbejdere. (I det tilfælde vil der selvfølgelig forekomme en minimal udjævning).

2. gennem en udjævning af de eksisterende uligheder i lønningerne ved at fastfryse de højere lønninger og give visse tillæg til de laveste lønninger. (Endelig vil der selvfølgelig foreligge en 3. mulighed ved at give tillæg til de højere lønninger og fastfryse de lavere lønninger. Denne mulighed vil jeg ikke omtale i det følgende.)

Disse to alternative strategier vil ud over de under punkt a) nævnte generelle effekter af en reduktion af lønsummen, virke i modsat retning i forhold til et gennemslag af en krises renselsesprocesser.

ad 1) En fastfrysning af de eksisterende uligheder i lønningerne. En sådan politik vil have en effekt i retning af at hindre udrensning af kapital i virksomheder, som er lavt profitable og som reproduceres i kraft af undergennemsnitlige lønninger (d.v.s. virksomheder som kun kan opretholde en vis profitandel ved at udbetale lønninger, der ligger under arbejdskraftens værdi); en udrensning som ellers ville have fundet sted ved en vis dynamik i lønbevægelserne, også i en krisesituation. Denne form for lønindgreb betyder altså, at et vist antal arbejdspladser opretholdes på kort sigt, men hindrer krisens rensende effekter i at sætte sig igennem og forlænger derved krisen.

ad 2) En fastfrysning af de højere lфnninger og tillag til de laveste. En sådan politik vil have en effekt i retning af at den fremmer en udrensning af de under punkt 1) omtalte kapitaler. Den skaber derfor umiddelbart en forøget arbejdsløshed, men på længere sigt vil den medvirke til at gennemsætte krisens renselsesproces og derved afkorte krisens varighed. 
Det kan her i øvrigt bemærkes, at det er denne effekt, som udenfor egentlige krisetider, har været et tilstræbt element i den svenske arbejdsmarkedspolitik siden slutningen af 1950'erne, som et led i en såkaldt strukturrationalisering indenfor de industrielle kapitaler. Denne politik er blevet gennemsat ved fagforeningernes solidariske lфnpolitik (fagforeningerne søger at sikre et ensartet lønniveau ved bestandigt at forsøge at presse de laveste lønninger i vejret). Denne solidariske lønpolitik er så blevet kompletteret med en aktiv statslig arbejdsformidlings- og arbejdskraftomstillingspolitik.

Herhjemme har der ikke været ført en sådan solidarisk lønpolitik og den statslige arbejdsformidlingspolitik har mere sigtet på, at fjerne eventuelle markedsmæssige barrierer for en effektiv tilpasning af lønningerne til de branche- og virksomhedsspecifikke akkumulationsbetingelser.

\section{c. Virkninger m.h.t. den i produktionsprocesserne anvendte teknik}

Jeg skal her kun ganske kort omtale dette forhold.

En reduktion af den samlede samfundsmæssige lønsum kan medvirke til at udskyde investeringer $i$ ny teknik, da arbejdskraft bliver billigere, og dermed forskydes den grænse, hvor det kan betale sig at erstatte arbejdskraft med fast kapital. Samtidig må det anføres, at et statsligt lønindgreb der billiggør arbejdskraften, på den anden side gør det mere fordelagtigt at foretage nyinvesteringer da den arbejdskraft, der skal anvendes pr. investeret kapitaldel, jo er blevet billigere. Men under krisen fører dette forhold ofte ikke til nye investeringer (udvidelsesinvesteringer), da der i forvejen findes uudnyttet kapacitet.

Men dette må ikke forlede til at slutte, at der ikke foretages investeringer i det faste kapitalapparat i krisen ud over egentlige erstatningsinvesteringer. Kapitalens problem i krisen er jo netop, at den investerede kapital må gøres mere profitabel. Dette kan kun ske ved, at der for hver enkelt kapitaldel sættes mere levende arbejde i bevægelse. Eller med andre ord: at arbejdskraften udnyttes mere intensivt. Nye investeringer må derfor medføre at den allerede bundne kapital bliver mere profitabel. Dette opnås i krisen ofte ved såkaldte rationaliseringsinvesteringer eller sekundærinvesteringer, som muliggør en økonomisering med såvel konstant som variabel kapital. 


\section{Den statslige lønreguleringspolitik siden 1974}

I det følgende skal jeg nu opridse hovedtrækkene i den faktisk førte statslige politik overfor lønudviklingen siden krisens gennemslag. Denne politiks hovedbestanddele har været en række indgreb dels overfor den såkaldte automatiske dyrtidsregulering og dels direkte i forhold til selve lønfastsættelsen.

Venstre-regeringen, som sad ved magten i krisens begyndelsesfase, forsøgte med mere traditionelle neoklassiske midler, specielt pengepolitikken, at opnå en omfordeling af industriens investeringer fra hjemmemarkedsog byggeindustri til exportindustrien og at opnå en omfordeling mellem løn og profit. Denne politik førte ikke til direkte indgreb i lønfastsættelsen, men bl.a. til udbetalingerne af de såkaldte omkostningsdampende ydelser (som skulle kompensere, som man sagde, for de forøgede omkostninger som de stigende lønninger påførte virksomhederne) og til en nulstilling af pristallet pr. 1. januar 1975.

Den socialdemokratiske regering, som tiltrådte i februar 1975, fortsatte den førte politik med udbetaling af omkostningsdæmpende ydelser til kapitalejerne.

I foråret 1975 greb regeringen ind i overenskomstforhandlingerne og forlængede overenskomsterne uændret; dog blev der givet et mindre tillæg til de lavest lønnede. Selv om arbejdsgiverne lagde op til en afskaffelse af dyrtidsreguleringen, blev denne bevaret, men ændret således, at der betaltes samme portion til alle, d.v.s. én dyrtidsportion var et fast beløb uanset den enkeltes hidtidige lønstørrelse. Herved skete der en vis reduktion af de højstlønnedes samlede lønstigning i forhold til de lavestlønnede.

Septemberforliget i 1975 indeholdt en såkaldt hensigtserklæring om, at staten skulle kompensere for de lønstigninger, der oversteg det beløb som svarede til én dyrtidsportions udbetaling - $\mathrm{i}$ henholdsvis januar og juli måned 1976.

Anden gang regeringen greb direkte ind i lønfastsættelsen var med det såkaldte augustforlig 1976.

Hovedindholdet i forligets lønpolitiske del var, at der i hvert af indkomstårene 1977/78 og 1978/79 kun måtte udbetales 2 dyrtidsportioner og den årlige lønstigning derudover ikke måtte overstige $2 \%$. Men denne $2 \%$ stigning i pengelønningerne blev ikke givet som et $2 \%$-tillæg til alle, men som en ramme hvorindenfor det samlede resultat af lønforhandlingerne indenfor LO-området skulle holdes. 
Dermed tog regeringen ikke stilling til hvorledes den samlede lønsum, som $2 \%$ rammen gav, skulle fordeles på de enkelte overenskomstområder. Dette overlod man til forhandlingsparterne selv.

En sådan politik medfører i det mindste to afgørende forhold, som begge vil medvirke til at lette gennemsættelsen af en statslig lønbegrænsningspolitik:

1. statens legitimitet i forholdet til arbejderklassen lider ikke så alvorligt et knæk, som hvis der var tale om en absolut og endelig fastsættelse af lønnen (dette gælder selvfølgelig i særdeleshed når det, som her, er Socialdemokratiet, der optræder som regeringsparti).

2. en splittelse i fagbevægelsen om lønrammens interne fordeling. I fagbevægelsens reaktioner på augustforliget viste der sig da også tydelige tegn på uenigheder om lønrammens fordeling. Disse blev mest iøjnefaldende repræsenteret ved Metalforbundets og SID's standpunkter.

Metalforbundet, hvis medlemmer traditionelt hører til de højstlønnede indenfor LO-området, reagerede på augustforliget ved at lægge op til en sprængning af 2\%-rammen og markerede, at det ikke ville afstå fra at kræve lønstigninger (underforstået: det ville ikke acceptere en politik, f. eks. fremført af LO, der udelukkende tillagde de lavtlønnede $2 \%$-stigningen). Ud over at man selvfølgelig ikke umiddelbart og frivilligt giver afkald på lønstigninger, var denne holdning dikteret af, at jern- og metalindustrien er minimallønsområde, dvs. lønnen ud over mindstelønnen, som forhandles centralt (forbundsplan), fastsættes ved lokal forhandling, som kan finde sted i hele overenskomstperioden p.g.a. den såkaldte løfteparagraf. Et overenskomstresultat, der på forhånd tillagde hele $2 \%$-rammens lønstigninger til de lavtlønnede, ville således kunne sætte hele metalforbundets lønforhandlingssystem ud af kraft; noget som ved tidligere statsindgreb i lønfastsættelse ikke havde været tilfældet, da disse blot var rettet mod selve minimallønnens fastsættelse. Tidligere statsindgreb i lønfastsættelsen, først og fremmest indgrebet i 1956 og helhedsløsningen i 1963 har derfor ikke haft afgørende virkning for Metalforbundets medlemmer, da det for dem er de lokale forhandlinger, der er afgørende for lønnens faktiske størrelse.

Specialarbejderforbundet, som er det forbund der har den største andel af de lavtlønnede og som forhandler efter normallønprincippet, krævede i sit udspil til forhandlingerne, at der foretoges en fordeling således, at 2\%-rammen fortrinsvist tildeltes de lavtlønnede. Men SID var i dette krav svækket af dets forholdsvis inhomogene sammensætning af medlemmer; det rummer også 
forholdsvis store grupper af højtlønnede. Samtidig var det også en svækkelse af SID, med dets i forvejen uforholdsmæssige store arbejdsløshedsprocenter, at en fordeling af lønsummen fortrinsvis til de lavtlønnede ville skabe en vis arbejdsløshed, som netop ville ramme hårdest indenfor dets eget område. ${ }^{18}$

Metalforbundet, derimod, stod forholdsvist stærkt med dets krav til forhandlingerne. Arbejdsløsheden var i sammenligning med andre områder moderat og forbundet har en ret homogen medlemsskare, da det stadigvæk i langt overvejende grad består af faglærte smede- og maskinarbejdere.

Umiddelbart efter augustforliget (1976) fremkom forskellige vurderinger af dets beskæftigelsesmæssige virkninger. Det blev hævdet, at Handelsministeriet lå inde med beregninger der vurderede de samlede virkninger til en stigning i arbejdsløsheden på ca. 20.000 personer årligt.

Foreningen Socialistiske Økonomer beregnede de negative virkninger på beskæftigelsen til 12.000 arbejdspladser årligt, for den lønpolitiske del af forliget alene, og når der korrigeredes for lønbegrænsningens positive virkninger på eksportstigninger og importreduktioner. Augustforliget som helhed beregnede $S \varnothing$ til en negativ virkning på beskæftigelsen på ca. 30.000 arbejdspladser årligt.

Disse tal skal selvfølgelig anskues med et vist forbehold, da de rummer mange usikkerhedsmomenter. Men selv med store forbehold viser beregningerne klart de umiddelbart negative virkninger i beskæftigelsesmæssig henseende af de lønreduktionistiske indgreb. ${ }^{19}$

Hvorledes virkningerne vil være på længere sigt, vil det nærmest være umuligt at vurdere.

Men hvor alvorligt regeringen mente sine lønpolitiske indgreb, på trods heraf, fik man et indtryk af i december 1976, som samtidig indvarslede en ny politik på et andet arbejdsmarkedspolitisk område, det arbejdsretslige. ${ }^{20}$

Under indtryk af en lang række overenskomststridige lønstrejker i efteråret 1976, hvor de strejkende forsøgte at opnå lønstigninger inden

18. Dette var også problemet ved overenskomstforhandlingerne i 1975 inden statsindgrebet, hvor SID ved forhandlingernes indledning i efteråret 1974, havde krævet forholdsvis store tillæg til de lavtlønnede, men senere afstod fra dette krav under indtryk af den kraftige tilbagegang i beskæftigelsen for specialarbejdere i vinteren 1974/75, idet man frygtede, at lavtlønstillæg ville skabe en yderligere arbejdsløshed.

19. Dette bekræftes da også af Det økonomiske Råd i Dansk Økonomi. November 1976, s. 66-67, selv om det fremstilles i slet skjulte vendinger.

20. Jeg tænker her bl. a. på de angreb, som statsmagten, specielt indenfor de sidste årstid, har anført overfor fysiske blokader som fagligt kampmiddel. 
augustforligets ikrafttræden pr. 1. marts 1977, lod regeringen sig presse af de borgerlige partier i folketinget, til at indgå på et forslag om en direkte civilretslig kriminalisering af overenskomststridige strejker, som førte til lønforbedringer. Forslaget blev dog ikke gennemført, p.g.a. modstand fra LO. Dansk Arbejdsgiverforenings formand Leif Hartwel udtalte, efter at forslaget var taget af bordet, at man ikke ønskede det.

Men selve forslagets fremkomst antyder en klar tendens bort fra den politik, som kom til udtryk under højkonjunkturen i den nye lov om arbejdsretten af 1973, der betød en afkriminalisering, i arbejdsretslig forstand, af overenskomststridige strejker af en varighed på op til 48 timer.

I stedet for dette forslag gennemførtes i december 1976 et $l \phi n-o g$ prisstop, som skulle gælde frem til augustforligets ikraftstrædelse pr. 1. marts 1977. Dette stop betød, at lønstigninger opnået ved overenskomststridige strejker kunne modregnes direkte i de opnåede stigninger ved overenskomsten 1977. Prisstoppet medførte at 1 dyrtidsportion, som ellers ville være opnået inden augustforligets ikrafttræden, ikke blev udløst.

Overenskomstforhandlingerne i foråret 1977 mellem LO og DA endte, ikke uventet, med et sammenbrud. Et mæglingsforslag fremsat af statens forligsmand blev vedtaget af arbejderne, men forkastet af arbejdsgiverne. Derefter blev forslaget ophøjet til lov, som det også blev kravet af LO. De væsentligste punkter i loven er en garanteret mindsteløn på $29 \mathrm{kr}$. i timen til alle arbejdere og en forhøjelse af samtlige tidlønsatser, for både minimal- og normallønsområdet, på i alt 4 rater á 70 øre fordelt halvårligt over hele overenskomstperioden (svarer til ca. $1 \%$ forhøjelse). Hertil indeholder det til lov ophøjede mæglingsforslag et protokollat om, at forudsætningen for disse satsforhøjelser er, at de ikke giver grundlag for en almindelig forhøjelse af lønniveauet; altså en bestemmelse som sigter på at begrænse lønglidningen. ${ }^{21}$

Sammenfattende kan det om det første mere langsigtede fors $\emptyset \mathrm{g}$ på indkomstpolitik (som de facto kun er lønpolitik) i Danmark siges: selv om reaktionerne i arbejderklassen på augustforliget (1976) var voldsomme og forlangte en sprængning af forliget, så lykkedes det ikke i perioden op til eller ved overenskomstforhandlingerne i foråret 1977 at foretage denne

21. Denne må således holdes indenfor ca. $1 \%$ årligt, hvis augustforligets bestemmelser skal efterleves. 
sprængning. Tværtimod, situationen blev vendt om, og LO måtte krave det mæglingsforslag, som var holdt indenfor forligets ramme, ophøjet til lov. Dette peger således i retning af, at den eksisterende industrielle reservearmé har varet en mere afgфrende faktor for begransningen af lфnudviklingen end den statslige lonpolitik. Denne kan i overensstemmelse hermed fortrinsvis ses som havende en slags katalysatorvirkning på den disciplineringsproces, som reservearmeens genetablering udløser i arbejderklassen. F. eks. kan indkomstpolitikken gøre det lettere for fagbevægelsens centrale instanser (LO og forbundsledelserne) at føre en mere tilbageholdende lønpolitik på trods af de mere militante dele af arbejderklassen. At en sådan defensiv lønpolitik i sidste instans er et resultat af den stærkt svækkede position, som krisen har påtvunget arbejderklassen, forhindrer ikke, at den førte lønpolitik kan dækkes ind under lovgivningsmagtens autoritet, som derved kommer til at virke som legitimation af fagforeningernes defensive politik overfor kapitalens skærpede udbytning af arbejderklassen.

Udviklingen indenfor metalområdet er her et oplagt eksempel. Efter augustforliget forlangte Metalforbundets formand Paulus Andersen en sprængning af forliget. Senere viste det sig meget vanskeligt for metalarbejderne at tilkæmpe sig lønstigninger via løfteparagraffen, mange steder måtte man tværtimod acceptere forringelser (jvf. udviklingen på skibsværfterne). Metalforbundet svingede da om og har siden ført en benhård politik imod lokale lønkampe indenfor dets eget område (eksempelvis Scaniadam-konflikten).

\section{Selektive statsindgreb overfor arbejdskraftreproduktionen}

I det foregående er det blevet fremhævet hvorledes krisens spaltning af arbejderklassen i beskæftigede og reservearmé betyder en manglende reproduktion - som arbejdskraft - af arbejderklassen som helhed, men at dette ikke er ensbetydende med nogen skranke for den nationale kapitalreproduktion. Tværtimod vil denne spaltning af arbejderklassen, som altså i sig selv er et resultat af kapitalens krise, være medvirkende til at gennemsætte kapitalens renselsesprocesser og dermed muligg øre dens reproduktion som kapital. Dette forudsætter naturligvis, at den etablerede reservearmé er fordelt på samtlige brancher således, at dens virkninger gør sig gældende indenfor alle brancher og ikke blot på nogle enkelte eller specifikt udsatte brancher (dvs. at reservearmeens tilstedeværelse bevirker en forøgelse af 
den nationale kapitals udbytningsgrad, og ikke blot, at nogle enkeltkapitaler tilraner sig en større andel af den samlede nationale profitmasse på bekostning af andre)..$^{22}$

Under forudsætning af en sådan fordeling vil arbejdskraftreproduktionen, i form af spaltningen mellem beskæftigede og reservearmé, være den mest adekvate, set i forhold til kapitalreproduktionen, under de givne akkumulationsbetingelser. Under disse forhold skal statsindgreb, der sigter på at tilvejebringe de bedst mulige betingelser for kapitalreproduktionen, derfor ikke være rettet mod at sikre den samlede arbejderklasses reproduktion som arbejdskraft, men mod at sikre, at de for kapitalen mest produktive (dvs. mest udbyttelige) arbejderne indgår i den beskaeftigede del af arbejderklassen. ${ }^{23}$

Sådanne indgreb må nødvendigvis være selektive overfor arbejderklassen, da de skal tilsigte dels, at en særlig del af denne (herunder på lidt længere sigt specielt de unge arbejdere) reproduceres som arbejdskraft og dels, at den for kapitalen mindst produktive arbejdskraft (herunder ældre/ nedslidte) forlader den beskæftigede del af arbejderklassen og reproduceres udenfor lønarbejdet.

Den følgende gennemgang af de statslige selektive indgreb overfor arbejdskraftreproduktionen i krisen vil vise, at disse faktisk i høj grad rummer tendenser, der kan medvirke til en sådan for kapitalen mest adekvat reproduktion af arbejderklassen og, at det således har været muligt at føre en sådan politik. ${ }^{24}$ Struktureringen af gennemgangen er bestemt af de fire hovedgrupper indenfor den industrielle reservearmé, som blev opridset i det foregående, og som de statslige selektive indgreb i hovedsagen retter sig imod. Specielt skal problemerne omkring de unge og de ældre/nedslidte arbejdere behandles.

22. At der faktisk i Danmark under den nuværende krise er tale om en fordeling af den industrielle reservearmé på samtlige brancher fremgår af opgørelserne af den samlede ledighed fra Danmarks Statistik fordelt på brancher. Se Tabel 3.01 i Statistiske Meddelelser: Arbejdsløsheden, div. årg.. De gennemsnitlige arbejdsløshedsprocenter for de enkelte brancher i året 1976 ligger ifølge Tabel 3.01 på mellem 9,0 og 14,4.

23. Denne betragtning er naturligvis kun gyldig i ren kapitallogisk forstand, og det er selvfølgelig ikke ensbetydende med, at det dermed også vil være tilfældet under givne historiske og politiske forhold.

24. Hermed menes, at arbejderklassen ikke gennem organiseret kamp har kunnet forhindre en sådan politik. Det er en del af formålet med denne artikel, at vise hvorledes det i krisen bliver tydeliggjort, at den statslige arbejdsmarkedspolitik, og de statslige arbejdskraftreproduktive politikker i $\emptyset$ vrigt, virker differentieret overfor arbejderklassens forskellige lag, aldersgrupper, branchegrupper, osv. og at dette differentierede gennemslag udspringer af kapitalens akkumulationsformer og -krav. Heri ligger i høj grad muligheder for fraktionering og splittelse i arbejderklassen. 
Siden 1975 er der over de statslige finanser bevilget penge (ca. 300 mill. kr. frem til midten af 1977) til forskellige former for beskæftigelse eller uddannelse af unge arbejdsløse. Problemet med sådanne foranstaltninger er som bekendt, at de ikke må betyde, at arbejde, der ellers ville være blevet udført på normal kapitalistisk vis, bliver udført med subsidier. De forskellige beskæftigelsesmæssige foranstaltninger for unge er derfor oftest ikke rettet direkte mod det almindelige lønarbejde, men kan være:

a. arbejdsmarkedsorienterende (f. eks. informationsvirksomhed om beskæftigelsesmuligheder for specielt unge på arbejdsmarkedet, erhvervsforberedende kurser)

b. uddannelsesmæssige (undervisning eller kurser med henblik på videreuddannelse eller opnåelse af erhvervskompetance)

c. beskæftigelsesforanstaltninger (egentlige beskæftigelsesarbejder som medvirker til en midlertidig opretholdelse af arbejdsevnen)

Set i forhold til antallet af unge arbejdsløse må midlerne til disse foranstaltninger dog siges at være meget beskedne og dermed også de beskæftigelsesmæssige virkninger.

Men disse foranstaltninger (særligt a) og b)) har en virkning på en anden måde, idet de, hos de arbejdsløse unge, kan medvirke til at opretholde troen på, at det er muligt at opnå beskæftigelse og derved opretholde selve motivationen til at være beskæftigelsessøgende. Derigennem kan foranstaltningerne også være medvirkende til at afbøde krisens demoraliserende effekter. Indenfor de egentlige erhvervsuddannelser for unge er der imidlertid også sket afgørende ændringer under krisens forløb.

Ved oprettelsen af EFG-uddannelserne i 1970, på forsøgsbasis, var det hensigten, at de erhvervsfaglige grunduddannelser skulle opbygges indenfor alle fagområder og, at mesterlæren skulle bortfalde i 1982. Desuden blev statsmagten direkte involveret i uddannelserne, dels gennem reguleringen af optaget og dels ved de statslige tilskud til lønnen på basisåret.

I krisen er der sket en stadig begrænsning af EFG-uddannelsernes udbygningstakt, og der har desuden, som nævnt i det foregående, vist sig stigende vanskeligheder med at opnå praktikpladser for EFG-elever samtidigt med en stigning i antallet af tilbudte mesterlærepladser.

I december 1976 indgås et forlig i folketinget som betyder, at lønnen på EFG-uddannelsernes basisår ikke kommer til at indgå i den endelige lov om uddannelserne. Ved vedtagelsen af den endelige og reviderede EFG-lov 
i juni 1977 stadfæstes denne afskaffelse af lønnen i basisåret samtidig med, at der åbnes mulighed for mesterlærens bevarelse. ${ }^{26}$

Bag denne revision af EFG-uddannelserne ligger givetvis de i krisen stadig tydeligere modsætninger mellem den tiltagende dekvalificeringstendens af de industrielle arbejdsprocesser samtidigt med EFG-uddannelsernes fortsatte og udvidede bidrag til udviklingen af det faglærte arbejderlag indenfor industrien. En sådan fortsat udvikling vil, specielt i krisen, kunne styrke de faglærte arbejdere på bekostning af de ufaglærte og derved skabe yderligere vanskeligheder for lønpolitiske styringsfors $\varnothing \mathrm{g} .{ }^{27}$

Set i en mere umiddelbar beskæftigelsesmæssig sammenhæng er det desuden klart, at basislønnens afskaffelse vil gøre EFG-uddannelserne mindre attraktive og betyde, at de unge atter i stigende grad indgår i den traditionelle mesterlære; nogle vil være tvungne hertil. Udbuddet af lærepladser er stigende, fordi lærlingene vil kunne anvendes som extrem billig arbejdskraft ${ }^{28}$ og en stor del af de unge har i krisen ikke andre muligheder for uddannelse eller endog beskæftigelse, når EFG-lærepladserne formindskes, lønnen på basisåret fjernes og der i øvrigt eksisterer eller indføres adgangsbegrænsning ved de øvrige uddannelsesmuligheder. Endvidere indeholder denne udvikling ikke umiddelbart den ovenfor omtalte modsætning, da mesterlærepladserne oftest ligger hos små håndværksmestre.

Endnu et forsøg på at bringe flere unge arbejdsløse i beskæftigelse er indeholdt i det såkaldte augustforlig II fra september 1977. Herefter kan der gives et statsligt finansieret løntilskud til private virksomheder, der forøger arbejdsstyrken ved at ansætte unge (dvs. under 25 år) arbejdsløse. ${ }^{29}$ Der er

26. Jvf. lov nr. 289 af 8 . juni 1977 om erhvervsfaglige grunduddannelser, $\S 16$ stk. 1, som blot bestemmer at undervisningsministeren kan ophæve adgangen til at indgå lærekontrakter efter mesterlæreloven indenfor et fag eller et geografisk område.

27. Jvf. artikel i Politisk Revy nr. 313 af Uddannelsesgruppen om »EFG-forliset«, som også indeholder en kortfattet omtale af de kampe som EFG-lærlingene har ført mod forringelser og indskrænkninger af uddannelserne.

28. Samtidig er det blevet mere $\varnothing$ konomisk fordelagtigt at beskæftige lærlinge, da betalingen for skoleophold i lærlingetiden ikke mere påhviler mesteren, som herved kan spare op til ca. 4000 kr. pr. lærling i forhold til tidligere. Jvf. Nyt fra arbejdsdirektoratet, nr. 10, 1975 s. 345.

29. Tilskuddet administreres af amts- og primærkommunerne. Der kan ydes tilskud med $10 \mathrm{kr}$. pr. arbejdstime for hver ung arbejdsløs virksomhedens samlede arbejdsstyrke udvides med. Tilskuddet kan gives i normalt 6 måneder, ved ansættelse af langtidsledige unge i op til 12 md. Ordningen omfatter også, at der kan ydes tilskud til vikaransættelser og til oprettelse af ekstraordinære lære- og praktikpladser (med max. 15.000 kr. pr. elev). 
i det mindste to bemærkelsesværdige forhold ved en sådan ordning. For det første: finansieres løntilskuddene over skatterne, vil de overvejende være en omfordeling mellem løn og profit, til profittens fordel. Heri adskiller en sådan ordning sig altså ikke fra omfordelinger i form af såkaldte omkostningsdæmpende ydelser eller statslige lønsumsreduktioner. Men en løntilskudsordning kan tages i anvendelse, frem for direkte lønreduktion, der hvor lønnen i forvejen ligger i nærheden af eksistensminimum. Men herigennem, og det er det andet bemærkelsesværdige forhold, kan en løntilskudsordning bevirke, at visse grupper arbejdere (her unge arbejdsløse under 25 år) beskæftiges frem for andre (f.eks. ældre arbejdere). Ordningen, som den her er praktiseret, kan altså have en vis push-effekt imellem aldersgrupperne således, at det i sidste ende er de ældste og nedslidte arbejdere, der bliver sorteper. Det vil, som vist i det foregående, også være det mest adekvate for kapitalreproduktionen. Denne udvikling forløber selvfølgelig også selv om staten ikke intervenerer med f. eks. løntilskud. Det bemærkelsesværdige er, at staten understøtter denne udviklingstendens.

Ældre/nedslidte arbejdere, som frisættes (udstødes) fra produktionsprocessen, kan i første omgang reproduceres (om end på et lavere niveau) udenfor denne via arbejdsløshedsunderst $\varnothing t t e l s e n$. Men da denne herhjemme er tidsbegrænset, ${ }^{30}$ må den arbejdskraft, som tvinges til at forlade arbejdsstyrken på grund af denne begrænsning, derfor på anden måde sikres mulighed for at opretholde livet. Det såkaldte augustforlig I (1976) følger da også et historisk traditionelt mønster, hvad angår pensionslovgivning i krisetider, hvor der åbnes flere muligheder for ældre arbejderes opnåelse af forskellige former for pension, samtidigt med at aldersgrænserne nedsættes.

Med augustforliget gøres det muligt at opnå førtidspensionering efter det fyldte 55 år. Da denne lovgivning også omfatter beskæftiget arbejdskraft, ligger der desuden heri et direkte incitament til ældre arbejdere om at forlade arbejdsstyrken.

30. Selve princippet med tidsbegrænset understøttelse, har eksisteret siden de første arbejdsløshedskasser blev oprettet på forsikringsbasis i 1870erne. Det var dengang en simpel nødvendighed, da relativt få langvarigt ledige ellers ville kunne tappe kasserne for deres begrænsede midler. Siden arbejdsløshedskasserne i 1907 har kunnet opnå statstilskud har tidsbegrænsningen været fastsat ved lov. Efter de nugældende regler skal en arbejder have haft arbejde i samlet mindst 26-uger indenfor de seneste 3 år for at bevare retten til dagpenge. 
Selve tidsbegrænsningen i retten til at oppebære arbejdsløshedsunderstøttelse $^{31}$ rammer naturligvis ikke kun ældre arbejdere, men samtlige arbejdere som falder for grænsen. Inden dette sker, vil en del arbejdere på grund af tidsbegrænsningen være tvunget til, at tage et nyt arbejde der både indholdsmæssigt og lønmæssigt er betydeligt ringere, end det de havde før deres arbejdsløshed indtrådte. Men en meget stor andel af de arbejdsløse, i den nuværende krise, har ikke haft blot denne mulighed, og der har da også fra dele af arbejderklassen og fagbevægelsens ${ }^{32}$ side, været ført en kamp for at omgå eller få reglen fjernet.

I løbet af foråret 1976, hvor en del af de, som blev arbejdsløse i 1974 eller før, havde meget snarlig udsigt til at falde for den såkaldte 26-ugers regel, ledte disse kampe til et pres på arbejdsministeren for, at få ham til at udstede et cirkulære til AF-kontorerne om, at de længst ledige skulle anvises føst arbejde; en praksis som arbejdsløshedskasserne tidligere har fulgt i vid udstrækning. Det blev imidlertid ikke til noget cirkulære, selv om ministeren på et tidspunkt tilsyneladende havde indvilget. Problemet er jo ganske enkelt det, at AF-kontorerne ikke kan pålægge kapitalejerne at antage den anviste arbejdskraft. ${ }^{33}$ Det ville jo være at antaste den private ejendomsret til produktionsmidlerne, hvis noget sådant kunne lade sig gøre, og det kan de åbenbart ikke. ${ }^{34}$

Bortset herfra ville det, som det fremgår af det foregående, være en, kapitalistisk set, dårlig politik at føre en sådan praksis, da det ville være den for kapitalen mindst produktive arbejdskraft, der herved ville komme i beskæftigelse.

Her viser det sig altså med al ønskelig tydelighed, hvad arbejderklassen (og fagbevægelsen) har mistet, da arbejdsanvisningen, med LO's accept, fratoges arbejdsløshedskasserne under 1960ernes højkon-

31. Dette er i øvrigt kun en rettighed såfremt man er medlem af en statsanerkendt arbejdsløshedskasse, da arbejdsløshedslovgivningen stadigvæk bygger på et frivilligt forsikringsprincip.

32. Især Det Centrale Arbejdsløshedsudvalg og progressive, ofte mindre forbund, har været aktive i denne kamp.

33. Desuden må det understreges, at AF-systemet lige siden dets oprettelse i 1967 har haft vanskeligt ved »at komme ind på markedet«; kun en meget lille andel af ansættelserne formidles af AF, ifølge AF's egne beregninger mellem 5 og 10\%. Et cirkulære som det omtalte ville have betydet yderligere vanskeligheder for AF.

34. Det kan derimod udmærket lade sig gøre, at antaste retten til at råde over egen arbejdskraft. Kun når visse betingelser er opfyldt, kan en arbejder nægte at modtage anvist arbejde. I skrivende stund (jan. 78) synes arbejdsministeren også, at dette er for galt og bebuder lovforslag, der bevilger arbejderen denne rettighed - i 1 (een) måned efter indtrædelsen af evt. arbejdsløshed. 
junktur. ${ }^{35}$ Dette var ganske vist noget, der ikke rigtig havde nogen værdi for arbejderklassen under højkonjunkturen, men den har ikke kunnet tilbageerobre de pågældende eller tilsvarende muligheder i krisen. ${ }^{36}$

Men problemet med de mange langtidsledige, der snart ville falde for 26-ugers reglen, pressede stadigvæk og i august 1976 vedtoges en lov således, at det tidsrum en arbejder kan opretholde understøttelse, uden at have haft i alt 26 ugers beskæftigelse, midlertidigt (frem til den 1/1-78) blev forlænget fra 3 til 4 år. Samtidigt indeholdt loven en dispensation fra reglen således, at ingen kunne falde for denne før d. 1/7-77. Hermed var problemet ikke løst, men udskudt.

I december 1977 vedtages atter en lov, der udskyder 26-ugers reglens virkninger, således at ingen kan falde for reglen inden den 1/1-79. Men denne lov får kun tilbagevirkende kraft fra den 15/11-77. Dermed blev de, der havde været arbejdsløse i 4 år uden mindst 26 ugers beskæftigelse indenfor tidsrummet 1/7 - 14/11-77, altså ofre for reglen.

En unders $\varnothing$ gelse foretaget af Arbejdsløshedskassernes Samvirke viser, at ca. 1000 langtidsarbejdsløse er blevet ofret. Heraf er de ca. 400 medlemmer af Specialarbejderforbundet, ca. 105 Kvindeligt Arbejderforbund, ca 200 HK'ere og de resterende ca. 300 fordelt på en lang række, fortrinsvis mindre forbund. Undersøgelsen viser samtidigt, at hvis ikke dispensationen fra 26-ugers reglen var givet, ville yderligere ca. 20.000 arbejdsløse have mistet deres understøttelse i tidsrummet frem til den 31/12-78. ${ }^{37}$

Bortset fra de, som allerede er faldet for reglen, har de langtidsarbejdsløse altså endnu engang fået en stakket frist. Selve det, at der kun har været tale om dispensationer og det lille »hul«, som skabtes mellem den 1/7 og 15/11, viser klart perspektivet for den kommende tid efter den 31/12-78. Selve tidsbegrænsningen af arbejdsløshedsunderstøttelsen vil ikke blive ophævet, og mange tusinde arbejdsløse vil blive tvunget til helt at forlade arbejdsmarkedet.

35. Jvf. Stat og arbejdsmarked, s. 71-73.

36. Også på dette punkt bebuder (jan. 78) arbejdsministeren forslag om, at arbejdsanvisningen atter skal kunne tillægges arbejdsløshedskasserne, efter ansøgning; altså under visse betingelser. Men dette vil ikke betyde, at arbejdsløshedskasserne vil kunne genetablere deres tidligere praksis med først ledig først i arbejde. Denne byggede jo på, at hvis en kapitalejer ikke antog en anvist arbejder, ja så ville han ikke blive anvist en anden, samtidig med, at det forudsatte indbyrdes solidaritet blandt de arbejdsløse. Men selv om a-kasserne atter får anvisningsret, ved siden af AF, vil AF forsat kunne pålægge arbejdere at tage anvist arbejde.

37. Undersøgelsen er på nuværende tidspunkt (30/1-78) ikke offentliggjort. 
Endelig skal det her fremhæves, at for den store gruppe af ufaglærte mænd og kvinder gennemføres der ikke specielle beskæftigelsesmæssige foranstaltninger, ved siden af de nævnte generelle foranstaltninger (omfattes af især augustforligene 1976 og 77). Arbejdsløse indenfor disse to grupper er derfor, hvis de vil forbedre deres chance for igen at komme i arbejde, næsten udelukkende henvist til at forbedre deres erhvervskompetance/kvalifikationer gennem deltagelse i specialarbejderkurser. Optaget på disse kurser er imidlertid begrænset; en del af kurserne kræver deltagelse i forudgående kurser, og endelig vil den tidligere beskæftigelse ofte være afgørende for hvilke kurser, en arbejder vil kunne optages på. ${ }^{38}$

Mulighederne for ad denne vej atter at komme i beskæftigelse, vil derfor, for disse store grupper, være ret begrænsede. Endelig vil dette ikke løse noget problem for arbejderklassen som helhed, da antallet af arbejdspladser jo ikke ændres herved. Tværtimod vil sådanne individuelle strategier forøge konkurrencen indenfor arbejderklassen eller kort sagt forøge trykket fra den industrielle reservearmé.

Dermed bliver det på den anden side også klart, at specialarbejderuddannelserne ingenlunde bliver overflødige i krisen, kapitalistisk set. Uddannelserne får nu i særlig grad den effekt, at de medvirker til at opretholde arbejdsevnen (reproducere de arbejdsløse som arbejdskraft) for de som optages på kurserne. ${ }^{39}$ Herigennem opretholdes samtidigt de arbejdsløses motivation til at søge beskæftigelse (jvf. det forudgående) og det sikres, at denne del af reservearmeen udgør en reelt virkende reservearmé (den dobbelte vedligeholdelsesfunktion).

Den omstillelighedsfunktion og bevægelighedseffekt, som specialarbejderuddannelserne sigtede på i 1960erne og begyndelsen af 1970erne, og som også skulle kompensere for manglen på en industriel reservearmé, vil derfor stadigvæk være gældende under kriseforløbet. Men specialarbejderuddannelserne vil nu ikke kompensere for, men direkte medvirke til

38. Endelig skal det her nævnes at for kvinderne, der jo i forvejen på grund af familie- og kønsrollemæssige forhold er særligt udsatte for arbejdsløshed, har den statslige krisepolitik været en faktor som har forstcerket deres udsatte position, jvf. f. eks. nedskæringerne på daginstitutionsområdet.

39. Kun $50 \%$ af de 42.909 kursister i 1976/77 havde haft fuld beskæftigelse de sidste 4 uger inden kurset. Af samtlige kursister havde 38\% været sikret beskæftigelse efter kurset samtidig med, at de havde haft fuld beskæftigelse i de sidste 4 uger inden kurset. Se Arbejdsmarkedsuddannelserne. Statistik 1976-77. Kbh. 1977. s. 47. 
at gennemsætte og forstærke reservearmeens tryk, idet de sikrer en rigelig tilstrømning af specialuddannede arbejdere til de områder, hvor der sker en (selv nok så beskeden) udvidelse af beskæftigelsen. ${ }^{40}$ Herigennem medvirker specialarbejderuddannelserne i krisen ikke blot til en kvalifikatorisk omstilling blandt de beskæftigede, men også til en kvalifikatorisk omstrukturering indenfor reservearmeen.

Den adskillelse mellem direkte lønindgreb og selektive indgreb overfor arbejdskraftreproduktionen, som har været indeholdt i den foregående fremstilling, skal selvfølgelig ikke opfattes derhen, at de selektive indgreb ikke har nogen lønmæssig effekt. Men adskillelsen fremkommer gennem det forhold, at de direkte lønindgreb, som det er fremstillet i det foregående, har til hensigt, at hæve profitraten generelt, og at dette indgreb ikke kræver nogen stoflig formidling, men kan foregå umiddelbart på det værdimæssige plan som indgreb i forholdet mellem løn og profit. Derimod må indgreb, der ikke sigter på arbejderklassens reproduktionsniveau generelt, udtrykt via lønstørrelsen, men som er betinget af de stofligt forskellige forudsætninger, som de enkelte arbejdskræfter besidder til at indgå i den kapitalistiske produktionsproces, så som alder, køn, kvalifikationer, fysisk og psykisk tilstand, m.v., og af kapitalens behov for arbejdskraft, formidles via disse stoflige forskelligheder for arbejdskraftreproduktionen. Den lønmæssige effekt af de selektive indgreb vil dermed være af indirekte karakter og vil primært være et resultat af de selektiv indgrebs effektivisering af den industrielle reservearmees virkemåde.

\section{Opsummering}

Skal der til slut opsummeres, aftegner der sig et billede af en politik, som nok til en vis grad har kunnet indvirke på det tids mæssige forløb af krisens renselsesprocesser på selve kapitalsiden, i det mindste i krisens begyndelsesfase, men hvis væsentligste funktion har været at påvirke kapitalens akkumulationsbetingelser $i$ en mere gunstig retning gennem regulering af arbejdskraftreproduktionen.

40. Der findes utallige eksempler på hvorledes en fabrik får uddannet f. eks. 30 specialarbejdere og derefter antager i alt 2 stk. Ofte vil der endog ikke være tale om egentlig nettoudvidelser af arbejdsstyrken, men om erstatning af hidtil beskæftiget arbejdskraft altså nyoptag i forbindelse med fyringer. 
Denne regulering har ikke sigtet på at reducere reservearmeens st $\phi r$ relse, snarere tværtimod, men har primært haft til funktion at sænke arbejderklassens reproduktionsniveau generelt og at gøre den eksisterende arbejdsstyrke mere produktiv. Dette er, foruden de direkte lønreduktionistiske indgreb, fors $\emptyset \mathrm{gt}$ ved, at de statslige interventioner har sigtet på:

- at medvirke til at de mest produktive arbejdere indgår i den beskæftigede del af arbejdsstyrken,

- at medvirke til at sikre kapitalen en reelt virkende reservearmé, og

- at sikre den for kapitalen overflødige arbejdskraft kan reproduceres udenfor lønarbejdet.

Herigennem bliver desuden klart, at den statslige regulering af arbejdskraftreproduktionen overfor arbejderklassen ikke er nogen homogen størrelse, men tværtimod vil virke differentierende overfor arbejderklassens reproduktion som arbejdskraft. Den vil derved, snarere end at virke i retning af en udjævning af de af kapitalen satte ulige betingelser for reproduktionen af arbejderklassens forskellige lag, være medvirkende til at fastholde disse uligheder. Når dette er tilfældet bliver de statslige politikker overfor arbejdskraftreproduktionen derfor en del af den genstand, som kampen mod kapitalens krise må rette sig imod. 
Tabel 1. Det samlede antal arbejdsløse ${ }^{1} 1973$ - 1978. Kvartalsvis

\begin{tabular}{|c|c|c|c|}
\hline & Mænd & Kvinder & I alt \\
\hline $\begin{array}{l}1973 \\
\text { januar kvartal } \\
\text { april kvartal } \\
\text { juli kvartal } \\
\text { oktober kvartal }\end{array}$ & $\begin{array}{r}26.000 \\
14.300 \\
8.400 \\
17.300\end{array}$ & $\begin{array}{l}5.800 \\
5.100 \\
3.900 \\
6.600\end{array}$ & $\begin{array}{l}31.800 \\
19.400 \\
12.300 \\
23.900\end{array}$ \\
\hline $\begin{array}{l}1974 \\
\text { januar kvartal } \\
\text { april kvartal } \\
\text { juli kvartal } \\
\text { oktober kvartal }\end{array}$ & $\begin{array}{l}27.000 \\
18.900 \\
32.200 \\
69.300\end{array}$ & $\begin{array}{r}9.100 \\
10.100 \\
12.700 \\
28.500\end{array}$ & $\begin{array}{l}36.100 \\
29.000 \\
44.900 \\
97.800\end{array}$ \\
\hline $\begin{array}{l}1975 \\
\text { januar kvartal } \\
\text { april kvartal } \\
\text { juli kvartal } \\
\text { oktober kvartal }\end{array}$ & $\begin{array}{r}100.000 \\
82.400 \\
73.400 \\
92.800\end{array}$ & $\begin{array}{l}37.600 \\
37.900 \\
38.600 \\
49.600\end{array}$ & $\begin{array}{l}137.600 \\
120.300 \\
112.000 \\
142.400\end{array}$ \\
\hline $\begin{array}{l}1976 \\
\text { januar kvartal } \\
\text { april kvartal } \\
\text { juli kvartal } \\
\text { oktober kvartal }\end{array}$ & $\begin{array}{l}99.700 \\
67.400 \\
66.700 \\
90.300\end{array}$ & $\begin{array}{l}48.100 \\
46.900 \\
50.800 \\
62.500\end{array}$ & $\begin{array}{l}147.800 \\
114.300 \\
117.500 \\
152.800\end{array}$ \\
\hline $\begin{array}{l}1977 \\
\text { januar kvartal } \\
\text { april kvartal } \\
\text { juli kvartal } \\
\text { oktober kvartal }^{2}\end{array}$ & $\begin{array}{r}104.900 \\
82.200 \\
79.500 \\
88.600\end{array}$ & $\begin{array}{l}65.900 \\
69.400 \\
74.000 \\
83.300\end{array}$ & $\begin{array}{l}170.800 \\
151.600 \\
153.500 \\
171.900\end{array}$ \\
\hline $\begin{array}{l}1978^{3} \\
\text { januar kvartal } \\
\text { april kvartal }\end{array}$ & $\begin{array}{r}115.900 \\
96.600\end{array}$ & $\begin{array}{l}90.300 \\
90.600\end{array}$ & $\begin{array}{l}206.200 \\
187.200\end{array}$ \\
\hline
\end{tabular}

Kilde: Arbejdsmarkedsnævnenes vurdering af beskæftigelses- og ledighedsudviklingen i januar og april kvartaler 1978. Arbejdsdirektoratet. Januar 1978.

1. Omfatter samtlige af AF-kontorerne registrerede fuldtidsforsikrede, deltisforsikrede og ikkeforsikrede ledige. Tallene er gennemsnit af arbejdsdirektoratets ugeopgørelser over arbejdsløsheden.

2. Omfatter perioden $5 / 10-6 / 121977$.

3. Tallene for 1978 er skøn foretaget af Arbejdsmarkedsnævnene. 


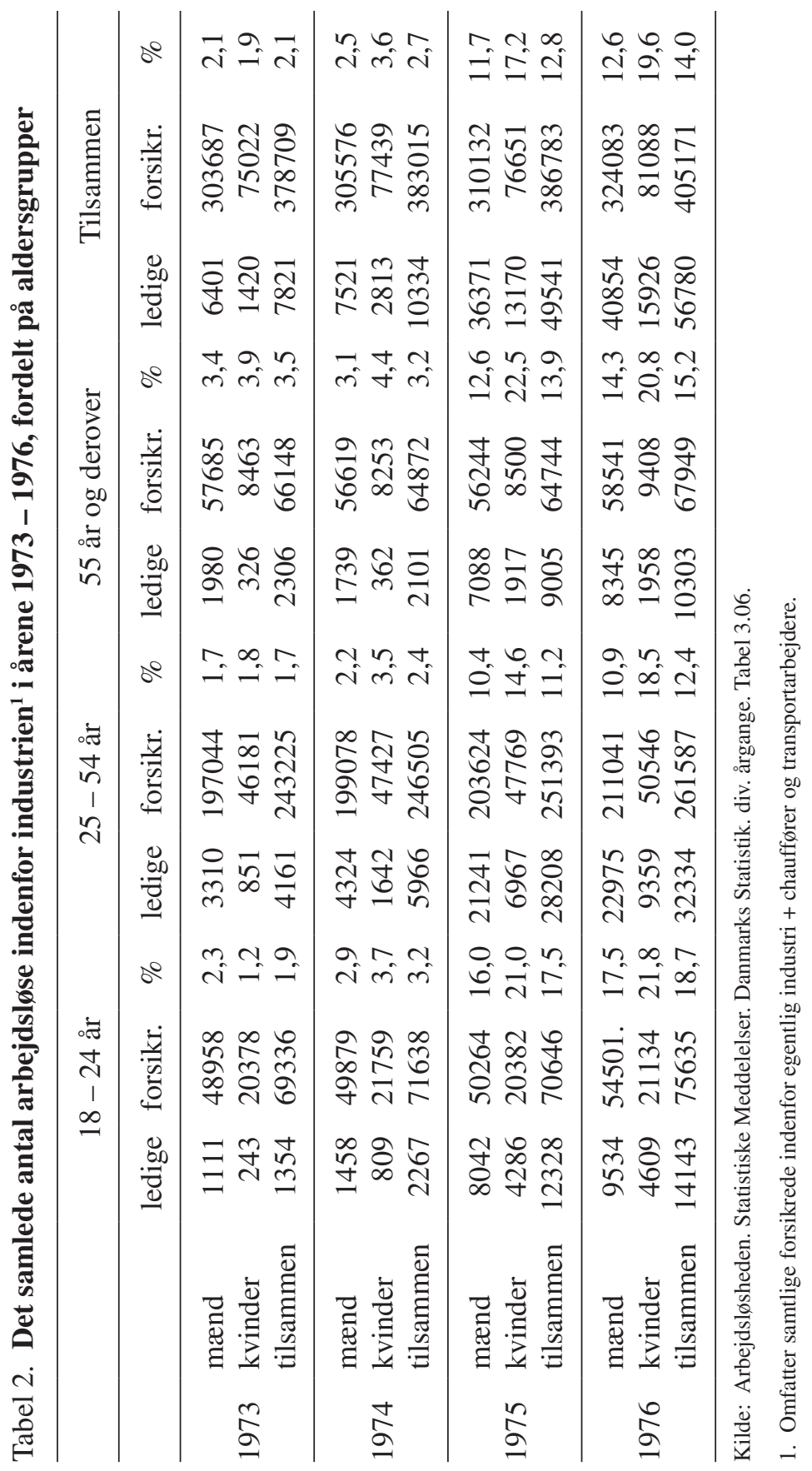


Tabel 3. Antal arbejdsløse og arbejdsløshedsprocenten for specialarbejdere ${ }^{1}$, mænd i øvrigt, kvinder og for samtlige arbejdsløshedsforsikrede $\mathrm{i}$ årene 1973 - 77

\begin{tabular}{lrrcccccccc}
\hline & \multicolumn{2}{c}{1973} & \multicolumn{2}{c}{1974} & \multicolumn{2}{c}{1975} & \multicolumn{2}{c}{1976} & \multicolumn{2}{c}{$1977^{2}$} \\
\hline & antal & $\%$ & antal & $\%$ & antal & $\%$ & antal & $\%$ & antal & $\%$ \\
\hline Specialarb. & 10570 & 4,1 & 18514 & 7,3 & 39649 & 15,2 & 34295 & 12,4 & 43880 & 15,1 \\
Mænd i $\varnothing v r$. & 8552 & 2,2 & 17330 & 4,2 & 38813 & 8,6 & 33546 & 6,7 & 42463 & 7,9 \\
Kvinder & 4662 & 2,6 & 11132 & 6,1 & 27713 & 12,8 & 33759 & 11,5 & 56222 & 15,9 \\
Samtlige & 23784 & 2,9 & 46976 & 5,5 & 106275 & 11,4101600 & 9,5141180 & 12,0 \\
\hline
\end{tabular}

Kilde: Arbejdsløsheden. Statistiske Meddelelser. Danmarks Statistik. Div. årange. Tabel 3.04 og Statistiske Efterretninger nr. 14, 1978. tabel 8.

1. Omfatter samtlige medlemmer af Specialarbejderforbundets arbejdsløshedskasse.

2. Tallene for 1973-76 er årsgennemsnit. For 1977 gennemsnittet for november måned.

Tabel 4. Arbejdsløshedsprocenten for kvinder og mænd indenfor gruppen fremstillingsvirksomhed. Årsgennemsnit for $1973-1977^{1}$

\begin{tabular}{lccrcccccccc}
\hline & \multicolumn{1}{c}{1973} & \multicolumn{1}{c}{1974} & \multicolumn{2}{c}{1975} & \multicolumn{2}{c}{1976} & \multicolumn{2}{c}{1977} \\
\hline & $\mathrm{K}$ & $\mathrm{M}$ & $\mathrm{K}$ & $\mathrm{M}$ & $\mathrm{K}$ & $\mathrm{M}$ & $\mathrm{K}$ & $\mathrm{M}$ & $\mathrm{K}$ & $\mathrm{M}$ \\
\hline Næringsmiddel & 3,9 & 1,5 & 8,7 & 3,4 & 19,4 & 7,8 & 19,4 & 7,4 & 28,0 & 9,7 \\
Textil & 2,4 & 1,8 & 10,1 & 6,0 & 21,4 & 14,1 & 15,7 & 9,4 & 27,1 & 12,3 \\
Beklædning og sko & 4,4 & 4,6 & 13,5 & 7,9 & 21,7 & 14,2 & 15,0 & 9,2 & 27,4 & 11,6 \\
Træ og møbel & 2,5 & 1,6 & 11,1 & 5,9 & 27,6 & 14,2 & 22,9 & 6,9 & 28,0 & 9,2 \\
Papir og graf. & 1,3 & 1,3 & 4,3 & 3,3 & 14,5 & 10,5 & 13,6 & 7,9 & 17,9 & 9,5 \\
Læder & 1,5 & 2,2 & 7,0 & 4,8 & 12,3 & 9,3 & 12,2 & 9,7 & 19,0 & 14,5 \\
Kemisk & 1,3 & 2,0 & 4,4 & 4,3 & 13,0 & 12,2 & 13,1 & 11,3 & 19,6 & 13,1 \\
Sten, ler, glas & - & 2,5 & - & 6,2 & - & 15,5 & - & 10,7 & 14,0 & 11,7 \\
Jern og metal & 2,0 & 1,6 & 7,2 & 3,4 & 22,8 & 9,8 & 19,8 & 8,8 & 25,6 & 10,5 \\
Anden industri & 1,7 & 2,2 & 6,3 & 5,1 & 15,5 & 13,1 & 15,0 & 9,5 & 21,0 & 13,0 \\
Fremst. i alt & 2,9 & 1,7 & 8,8 & 3,9 & 20,4 & 10,4 & 17,6 & 8,6 & 25,6 & 10,5 \\
& & & & & & & & & &
\end{tabular}

Kilde: Arbejdsløsheden. Statistiske Meddelelser. Danmarks Statistik. Div. årgange. Tabel 3.01 og Statistiske Efterretninger nr. 14 1978. tabel 8.

1. 1977 omfatter kun gennemsnittet for november måned. 